\title{
Cellular Bioreactivity of Micro- and Nano-Plastic Particles in Oysters
}

\author{
Tamara R. Gaspar, Richard J. Chi, Matthew W. Parrow and Amy H. Ringwood* \\ Department of Biological Sciences, University of North Carolina at Charlotte, Charlotte, NC, United States
}

The global usage of plastics has increased dramatically over the last several decades. Polystyrene (PS) is the fourth most common plastic material produced annually due to its many versatile applications. Consequently, there has been a coinciding increase in PS wastes, much of which makes its way into waterways and oceanic habitats. While plastic debris has been shown to adversely affect many marine species as a result of ingestion and entanglement, less is known about the cellular uptake of small-scale plastic particles (nano and micro) by marine invertebrates. In this study, we investigated the potential for uptake of PS nano and micron-sized beads (50 nm and $3 \mu \mathrm{m}$ ) by the Eastern Oyster, Crassostrea virginica. This research was focused on two key issues: (1) how particle size would affect uptake by hepatopancreas (HP) cells in vitro and (2) the difference in uptake of micron and nano particles in vivo between gill and HP

OPEN ACCESS

Edited by: Juan Jose Alava, University of British Columbia, Canada

Reviewed by:

Ana Tirapé

Escuela Superior Politecnica del Litoral (ESPOL), Ecuador Gabriela Verónica Aguirre-Martínez,

Universidad Arturo Prat, Chile

*Correspondence:

Amy H. Ringwood ahringwo@uncc.edu

Specialty section:

This article was submitted to Marine Pollution,

a section of the journal

Frontiers in Marine Science

Received: 29 April 2018 Accepted: 07 September 2018 Published: 10 October 2018

Citation:

Gaspar TR, Chi RJ, Parrow MW and Ringwood AH (2018) Cellular Bioreactivity of Microand Nano-Plastic Particles in Oysters.

Front. Mar. Sci. 5:345,

doi: 10.3389/fmars.2018.00345 tissues. This research confirmed that oysters can accumulate PS beads in their tissues, especially HP tissues. Furthermore, using fluorescent deconvolution microscopy, it was observed that plastic nanoparticles exhibited a much greater propensity for intracellular accumulation in HP cells, primarily into lysosomes via endosomal pathways, indicating the potential for significant bioreactivity and sublethal impacts. While exposures of whole oysters or isolated HP cells to bare PS beads did not cause any significant toxicity (acute or sublethal), nanoplastics are more likely to accumulate intracellularly and to deliver adsorbed toxins directly into cells.

Keywords: nanoplastics, microplastics, plastics, nanoparticles, oysters, lysosomes

\section{INTRODUCTION}

The presence and effects of plastic particles in ocean waters and aquatic organisms are serious current and emerging issues of increasing concern. Barnes et al. (2009) reported that more than 200 million metric tons of plastic were produced annually, and more recently, it was estimated that in 2016, 335 million tons of plastic were produced (PlasticsEurope, 2018). Disposable packaging is the largest market sector, and additional sources include microplastics from common household products such as toothpaste, facial exfoliators, and hand cleaners (Derraik, 2002). As global production of plastics increases and improper handling of plastic wastes continues, an ever-increasing quantity of plastic makes its way into aquatic ecosystems - freshwater waterways, estuarine and coastal systems, and the open ocean. Based on plastic production estimates and estimates of inputs of plastic wastes, especially mismanaged wastes (from inadequate disposal and littering), from 190 coastal countries, it was estimated that oceanic inputs in the same time frame could range from 5-10 million metric tons, and by the year 2025 plastic waste inputs into marine systems will could be as much as 100-250 million metric tons (Jambeck et al., 2015). Entanglement and ingestion of large pieces of plastic debris (ropes, nets) and plastic bags for 
turtles, marine mammals, sea birds can be catastrophic and alarming to the public as well as scientific communities. More recently serious concerns about small plastic pieces in the micron range have been realized. While less visible nanoplastics cannot yet be readily quantified, they are likely to be present. Small pieces of plastic in the micron- and nano-size ranges are the result of degradation processes, primarily fragmentation of plastic products and debris, as there is very little true degradation (chemical breakdown into different or base compounds; Mattsson et al., 2015). Degradation/fragmentation via natural weathering processes has been shown to start in as little as 8 weeks (Weinstein et al., 2016). Fragmentation can also be the result of biological processes, especially behaviors involving jaws/teeth, claws, scraping, or grinding parts. Commercially produced beads, often used in personal care products as well as a variety of commercial applications, are another important source of small plastic particles. Ultimately these small micron-size pieces and nanoparticles smaller than $1 \mu \mathrm{m}$, as well as adsorbed pollutants, are readily available for consumption by a multitude of organisms including marine invertebrates and larval forms (Teuten et al., 2007; Andrady, 2011; Martins and Sobral, 2011; Cole et al., 2013; Cole and Galloway, 2015; Weinstein et al., 2016; Gray and Weinstein, 2017).

Organisms across trophic levels, from top level predators to zooplankton, have been found to ingest plastic marine debris in the natural environment, and estuarine organisms have been shown to have higher levels of plastic wastes in their guts compared to open ocean organisms (Cadée, 2002; Denuncio et al., 2011; Cole et al., 2013). Laboratory studies have also confirmed the capacity of estuarine organisms to accumulate microplastics (Bocchetti et al., 2008; Ward and Kach, 2009; Wegner et al., 2012), and translocation of plastic particles from the gut to the circulatory system has been reported in mussels (Browne et al., 2008). The focus of this research was the cellular accumulation of micron-sized $(3 \mu \mathrm{m})$ and nano-sized $(50 \mathrm{~nm})$ polystyrene (PS) particles in the tissues and cells of oysters, Crassostrea virginica. Oysters like other sessile bivalves have been widely recognized worldwide as valuable bioindicators species of aquatic pollution. As part of their filter-feeding lifestyle, oysters and other bivalves are reknown for their high filtration rates, processing of large volumes of water and suspended sediments to as they are actively engaged in removing particles as they process large volumes of water and concentrate phytoplankton, pollutants, and particulates (Kennedy et al., 1996; Coen et al., 2007; Farrington et al., 2016). Oysters are therefore a likely major target species of plastic particles in coastal ecosystems, and are also well-recognized for their value as laboratory models for characterizing nanoparticle bioreactivity (Canesi et al., 2012; McCarthy et al., 2013; Faggio et al., 2018). In vivo studies were conducted to test the hypothesis that gill and hepatopancreas (HP, also known as digestive gland) tissues of whole adult oysters would exhibit differential uptake of PS particles based on particle size. In vitro studies were conducted using isolated cells to test the hypotheses that nano-sized particles would be taken up more readily by HP cells than micron-sized particles. Both in vivo and in vitro studies were used to assess potential toxicity and cellular accumulation to characterize bioreactivity.

\section{MATERIALS AND METHODS}

\section{Animal Care and Exposure Conditions}

Adult Eastern oysters (approximately 6-8 cm from hinge to shell margin), Crassostrea virginica, collected from Bogue Sound, NC, United States, were maintained in laboratory aquaria at room temperature $\left(20-23^{\circ} \mathrm{C}\right)$ under ambient light conditions $(12 \mathrm{~h}$ light:12 h dark); salinity, dissolved oxygen, and $\mathrm{pH}$ were routinely monitored and maintained between 25; 30\% salinity, 70-90\% dissolved oxygen, and 7.8-8.2 pH units). All seawater (SW) used for laboratory culture and exposures contained a mixture of natural SW, collected off the North Carolina coast, and artificial SW (Instant Ocean ${ }^{\mathrm{TM}}$ ) at a ratio of $2 / 3$ Instant Ocean to $1 / 3$ natural SW. Aquaria (80 L volume) were kept under constant aeration and carbon filtration was alternated every other day with feeding (carbon filters were removed, and the animals were fed cultured algae $\left(200 \mathrm{~mL}\right.$ of $10^{6}$ algae/mL), Isochyrsis galbana (CCMP462, Bigelow Laboratory for Ocean Sciences) cultured in $0.22 \mu \mathrm{m}$ filtered, autoclaved SW with $\mathrm{f} / 2$-Si medium). Oysters were acclimated to the tank and laboratory conditions for 1-2 weeks before use in experiments.

The $3 \mu \mathrm{m}$ and $50 \mathrm{~nm}$ fluorescent PS particles used in this study contained a fluorophore incorporated into the particle during preparation by the manufacturer (Spherotech, FP-3052-2 and FP-00552-2, respectively). A stock solution of $100 \mathrm{mg} / \mathrm{L}$ was prepared in deionized (DI) water and vortexed to obtain a homogeneous mixture. Serial dilutions were made in filtered SW/Instant Ocean mix ( $0.22 \mu \mathrm{m}$ filtered) to produce PS exposure concentrations of 10,50 , and $100 \mathrm{ppb}(\mu \mathrm{g} / \mathrm{L})$.

Dynamic light scattering (DLS) was utilized to assess the effects of concentration and SW on particle size using a Zetasizer Nano ZS (Malvern Instruments). PS solutions for DLS were prepared in the same manner as the exposure solutions (above) using both DI water and the SW mix at concentrations of 10, 50, and $100 \mathrm{ppb}$. The DLS analyses were conducted using a refractive index of 1.590. The average particle sizes reported are based on readings from 2 different exposure days.

\section{In vitro Exposures}

Primary cell cultures of HP cells were generated using standard techniques (Ringwood et al., 2005). Briefly, pieces of HP tissue (approximately $5 \mathrm{~mm}^{3}$ ) were dissected, kept cold, chopped with a scalpel, placed into a 24-well culture plate, and shaken in calcium magnesium free saline (CMFS) and trypsin for $40 \mathrm{~min}$. After shaking, tissues were sheared using glass Pasteur pipettes and filtered through $41 \mu \mathrm{m}$ mesh screens into microcentrifuge tubes. The cells were washed twice using gentle centrifugation in CMFS and then transferred to $60 \mathrm{~mm} \times 15 \mathrm{~mm}$ glass exposure dishes containing $8 \mathrm{~mL}$ of exposure solution of a 1:1 mixture of CMFS and SW for control, $10 \mathrm{ppb}$ PS, or $100 \mathrm{ppb}$ PS treatments, and exposed for $4 \mathrm{~h}$ with gentle shaking throughout, which served to keep the particles in suspension and maximized contact with the tissues. Each treatment was replicated in six separate dishes 
with $\mathrm{pH}$ maintained between $7.4-7.5$ to mimic physiological conditions. A $1 \mathrm{~mL}$ subsample of cells was taken before the addition of PS (starting control, $0 \mathrm{~h}$ ), and at 1,2, and $4 \mathrm{~h}$ for all treatments, and fixed in $1 \%$ buffered formalin for review under fluorescent microscopy. Subsamples of live, unfixed cells were taken for lysosomal destabilization analysis at 0 and $4 \mathrm{~h}$. These studies were used to characterize the potential for uptake and toxicity of PS particles in isolated HP cells (in vitro) of oysters.

\section{In vivo Exposures}

Groups of three oysters were placed in $2 \mathrm{~L}$ beakers (two replicates per treatment) and exposed to $1.2 \mathrm{~L}$ of SW mix with control and $50 \mathrm{ppb}$ PS particle solutions for $48 \mathrm{~h}$ with constant aeration to maintain circulation of plastic spheres. The exposure conditions were comparable to the acclimation conditions $\left(20-23^{\circ} \mathrm{C}, 12 \mathrm{~h}\right.$ light: 12 h dark light regimes, 25-30\% salinity, 70-90\% dissolved oxygen, and 7.8-8.2 pH units). Beakers were covered throughout the exposure with parafilm to prevent contamination of particles from the air. At the end of the exposure period, oysters were removed from the treatment water and placed in clean SW for a 1-h depuration period to allow for some cleansing of extraneous PS particles. Oysters were then sacrificed and freshly dissected HP tissues were used for lysosomal destabilization assays. Samples of gill and HP tissues were also processed to isolate cells that were fixed in $1 \%$ buffered formalin for fluorescent microscopy. These studies were used to characterize the potential for uptake and toxicity of PS particles in vivo, in whole adult oysters.

\section{Lysosomal Destablization}

Lysosomal destabilization assays have been used widely as a valuable, very sensitive cellular damage assay (Regoli, 1992; Ringwood et al., 2005; Moore et al., 2014). Briefly, HP tissue samples, approximately $5 \mathrm{~mm}^{3}$, were processed into primary cell preparations with CMFS and trypsin and filtered through a $41 \mu \mathrm{m}$ nylon screen. After the cells were rinsed and re-suspended in CMFS (final volume between $80-120 \mu \mathrm{L}$ depending on pellet size), a working solution of neutral red (NR; $0.04 \mathrm{mg} / \mathrm{mL}$ ) was added at a 3:2 ratio of NR to cell preparation volume for a final concentration of $24 \mu \mathrm{g} / \mathrm{mL}$. After a $60 \mathrm{~min}$ incubation period, cells were scored as either stable (NR contained within the lysosomes) or destabilized (NR diffusing into the cytoplasm from damaged lysosomes) at 400x magnification, with at least 50 cells scored from each preparation.

\section{Fluorescent Microscopy}

Fixed cells were rinsed twice in CMFS to remove freely suspended PS particles (centrifugation at $200 \mathrm{~g}$ for $5 \mathrm{~min}$, removed the supernatant, and re-suspended in fresh buffered formalin). After the final rinse, cells were re-suspended in a total volume of $200 \mu \mathrm{L}$ to concentrate the cells. Subsamples of cells were mounted on slides and analyzed using the Zeiss Axio Observer with the Fluo3 filter (ex. $400+495+570$; em. $460+530+625)$ at $400 x$ total magnification. One hundred cells per animal ( $n=6$ replicates/treatment) were scored as fluorescing or not fluorescing, and the percent fluorescing cells was determined. Cells were also analyzed using the Delta Vision Elite deconvolution microscope at $600 \mathrm{x}$ total magnification which allowed for greater resolution and determination of cellular location of PS.

\section{Statistics}

All data were analyzed using Sigma Stat 2.0 or GraphPad Prism 6. Replicate beakers and experiments/treatments performed on separate dates were compared using ANOVA or $t$-test analyses; there were no significant beaker effects or experiment date effects, so statistical analyses were based on treatment. Significant differences between treatments were determined using either a one-way ANOVA analysis (confirmed normality and equal variance) or ANOVA on ranks. Pairwise comparisons were performed using the Student-Newman-Keuls method. Regression analyses were conducted to evaluate trends associated with time or exposure concentration.

\section{RESULTS}

\section{Particle Sizing}

To evaluate PS nanoparticle characteristics and behavior in SW, DLS was conducted on subsamples of the $50 \mathrm{~nm}$ particle solutions. The sizes of the PS nanoparticles were generally consistent with the size reported by the manufacturer in both DI water and SW, indicating that there was no significant agglomeration for the tested concentrations and maintained the manufacturer reported size (Table 1). In SW, there was no significant increase in particle size across all treatments, although the highest particle size (and greatest variation in size) was observed at the highest PS concentration. Therefore, based on DLS studies, the particles were very stable and did not show high rates of agglomeration even in SW.

\section{Particle Toxicity Studies}

Lysosomal destabilization was used as an indicator of cellular toxicity for both in vivo and in vitro exposures. After both the 4-h in vitro and 48-h in vivo exposures, there was no evidence of toxicity for any of the particle types or concentrations for both time frames (Figure 1). This assay is used routinely in our laboratory for toxicity studies, and background levels of 20-25\% are typical of control or nontoxic conditions; and levels below $30 \%$ are regarded as not biologically significant (Ringwood et al., 2004). Typically, statistically and biologically significant increases in lysosomal destabilization with toxic nanoparticles as well as

TABLE 1 | Summary of polystyrene (PS) particle size studies with DLS (mean \pm standard deviation) in dionized (DI) water or seawater (SW, 25\% salinity).

\begin{tabular}{lcc}
\hline Media & [PS NP] $(\boldsymbol{\mu} \mathbf{g} / \mathbf{L})$ & Average size \pm SD $(\mathbf{n m})$ \\
\hline DI & 10 & $59.3 \pm 2.8$ \\
DI & 50 & $59.4 \pm 1.5$ \\
DI & 100 & $61.1 \pm 5.9$ \\
SW 25\%o & 10 & $60.3 \pm 4.3$ \\
SW 25\%o & 50 & $59.6 \pm 6.3$ \\
SW 25\%o & 100 & $68.1 \pm 11.0$ \\
\hline
\end{tabular}

Means based on sample sizes of six replicates from two different exposure days. 

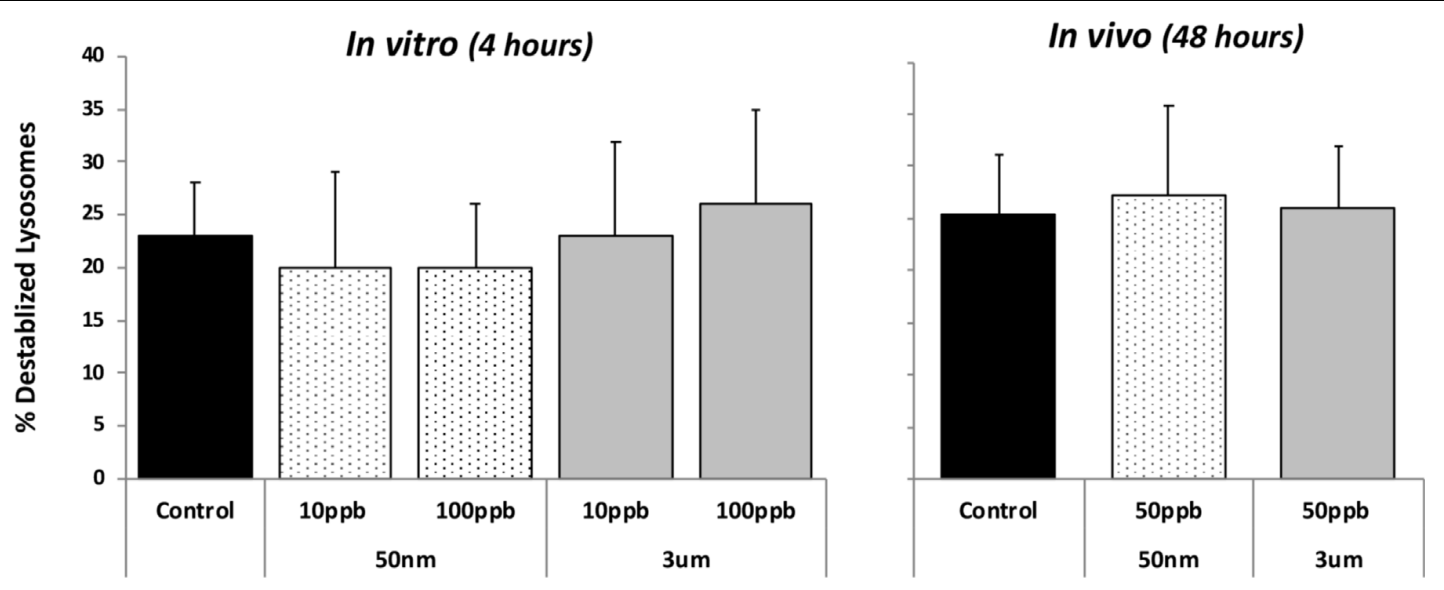

FIGURE 1 | Lysosomal destabilization in HP cells after in vitro (4 h) and in vivo (48 h) exposures to fluorescent polystyrene (PS) beads of different sizes (50 $\mathrm{nm}$ and $3 \mu \mathrm{m}$ particles). Data are means and standard deviations. No significant differences were detected between controls and any of the treatments.

dissolved pollutants are observed in less than $24 \mathrm{~h}$ (Ringwood et al., 1998; McCarthy et al., 2013).

\section{In vitro Cellular Accumulation Studies}

Epifluorescent microscopy analyses were first used to assess the potential for cellular accumulation of PS particles. Using epifluorescent microscopy at 400x, the $3 \mu \mathrm{m}$ PS particles are large enough to be viewed and provide verification of detection (Figure 2A). While individual nano-sized particles in solution cannot be seen at this magnification, they can be detected in cells when multiple particles are localized together. Using epifluorescent microscopy at 400x, both PS nanoparticles and microparticles were found with oyster HP cells exposed in vitro for $4 \mathrm{~h}$ (Figure 2). For HP cells exposed in vitro to $50 \mathrm{~nm}$ particles at two concentrations (10 and $100 \mathrm{ppb}$ ), there was a significant difference in presence across different time points (ANOVA, $p<0.001$ ), with increasing incidence of fluorescing cells over time (Figure 3). While slightly higher percentages of fluorescent cells were observed for the $100 \mathrm{ppb}$ treatment, there were no significant differences between exposure concentrations for the different time points. Regression analysis based on exposure duration indicated a significant increase with time $[0,1,2$, and $4 \mathrm{~h}$; analysis based on individual replicates, $n=6$ for each

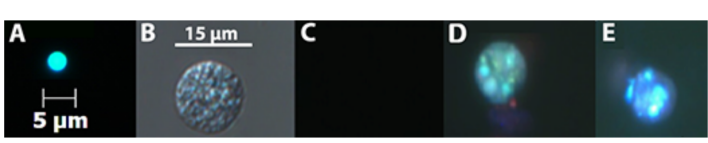

FIGURE 2 | Representative HP cells as viewed using light and epifluorescent microscopy with the Zeiss Axio Observer, 400x magnification: (A) fluorescent microscopy image of a $3 \mu \mathrm{m}$ particle viewed at $400 x$ using the Zeiss Fluo3 filter set 25(excitation $400+495+570$, emission $460+530+625$ ); (B) HP cell under light microscopy; (C) control HP cell using the Fluo3 filter set showing absence of fluorescence or polystyrene particles; (D) HP cell and associated $50 \mathrm{~nm}$ polystyrene particles; and (E) HP cell and associated $3 \mu \mathrm{m}$ polystyrene particles. Scale bar in $\mathbf{B}$ is also applicable for $\mathbf{C}-\mathbf{E}$.

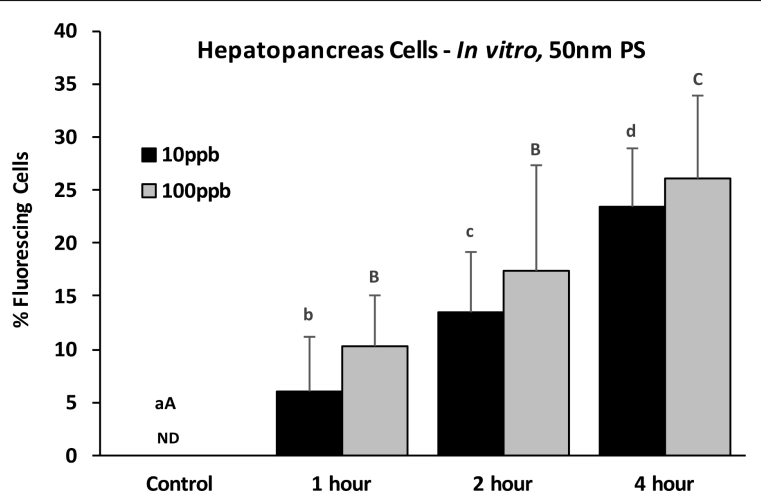

FIGURE 3 | Percent fluorescing cells based on epifluorescent analysis (Zeiss Axio Observer, 400x magnification) after exposure of HP cells in vitro to $50 \mathrm{~nm}$ polystyrene particles at two concentrations (10 and $100 \mathrm{ppb}$ ) for 0, 1, 2, and $4 \mathrm{~h}$. Values are means + standard deviations. Letters indicate significant differences between time points within a concentration. ND, not detected. $n=6$ replicates/treatment; $\geq 100$ cells/replicate, $p<0.05$.

time point; $10 \mathrm{ppb}-F(1,22)=86.7, p<0.0001, r^{2}=0.80$; $\left.100 \mathrm{ppb}-F(1,22)=45.5, p<0.0001, r^{2}=0.67\right]$.

Similarly, when HP cells were exposed in vitro to $3 \mu \mathrm{m}$ particles, there were significantly more fluorescing cells at $2 \mathrm{~h}$ than at $1 \mathrm{~h}$, but plateaued after $2 \mathrm{~h}$ and there were no differences between 2 and $4 \mathrm{~h}$ (Figure 4). While there were no significant differences between concentrations at each time point, there was a tendency for higher levels for the $10 \mathrm{ppb}$ treatment.

Epifluorescent microscopy indicated cellular associations that includes both intracellular PS particles and PS particles that are bound externally. Deconvolution microscopy was used to confirm intracellular accumulation of PS particles. After review of the HP cells exposed to $100 \mathrm{ppb}$ of micro- and nanoparticles using deconvolution microscopy, it was determined that only the $50 \mathrm{~nm}$ particles were internalized by cells (Figures 5, 6) with a significant difference in uptake across time points (ANOVA, $p=0.0002$ ). The $3 \mu \mathrm{m}$ PS particles were only observed on the 


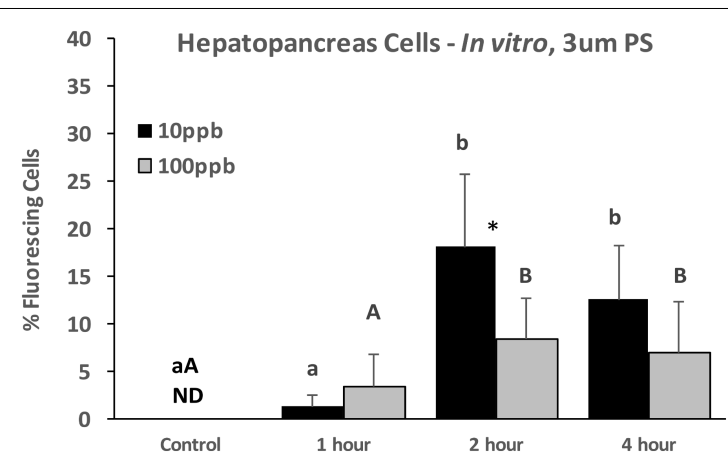

FIGURE 4 | Percent fluorescing cells based on epifluorescent analysis (Zeiss Axio Observer, 400x magnification) after exposure of HP cells in vitro to $3 \mu \mathrm{m}$ polystyrene particles at two concentrations (10 and $100 \mathrm{ppb}$ ) for $0,1,2$, and $4 \mathrm{~h}$. Values are means + standard deviations $(n=6)$. Letters indicate significant differences between treatments. An* indicates a significant difference within a time point $(p<0.05)$. ND, not detected.

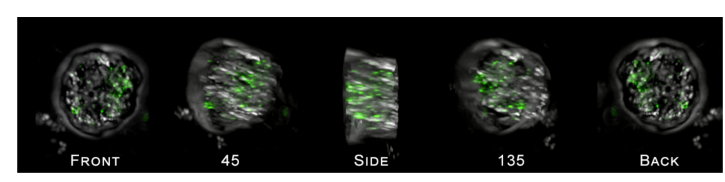

FIGURE 5 | Cross section of a single HP cell exposed to $50 \mathrm{~nm}$ PS particles as viewed using the DeltaVision Elite deconvolution microscope (600x magnification), rotated around the $y$-axis of the cell by $180^{\circ}$. Images show the presence of $50 \mathrm{~nm}$ polystyrene bead clusters inside the cell. A movie of the images showing the rotation of the cell is provided in the Supplementary Files.

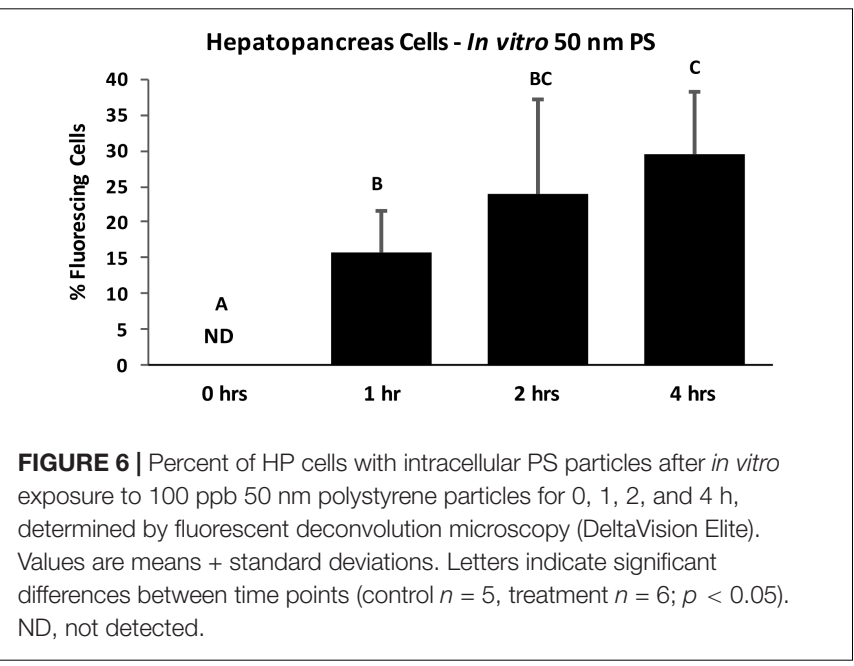

exterior of cells. Moreover, the percentage of cells exposed to $100 \mathrm{ppb} 50 \mathrm{~nm}$ particles was not significantly different at each time point from the percent determined using the epifluorescent microscope (compare Figures 3, 6).

\section{In vivo Exposures}

To compare if particle uptake occurred in the gills, in the HP tissues, or both of whole adult oysters, 48-h in vivo exposures were conducted using $50 \mathrm{ppb}$ of $50 \mathrm{~nm}$ and $3 \mu \mathrm{m}$ particles. Epifluorescent microscopic analyses at 400x magnification indicated that both $50 \mathrm{~nm}$ and $3 \mu \mathrm{m}$ PS particles were found with both HP and gill oyster cells when exposed in vivo, with consistently higher HP cells compared to gills. There was a slightly higher incidence of $50 \mathrm{~nm}$ particles compared to $3 \mu \mathrm{m}$ particles in HP cells, but the differences were not significant. In gill cells, the incidence of fluorescing cells was significantly higher for the $50 \mathrm{~nm}$ PS particles compared to the $3 \mu \mathrm{m}$ PS particles (Kruskal-Wallis one-way ANOVA on ranks, $p<0.001$ ).

The HP tissues had a significantly higher accumulation of PS particles than the gills with both $50 \mathrm{~nm}(p=0.045)$ and $3 \mu \mathrm{m}$ ( $t p=0.026)$ particles (Figure 7). The HP cells were further analyzed using deconvolution microscopy which indicated that only $50 \mathrm{~nm}$ PS particles were internalized by HP cells; no intracellular particles were detected for $3 \mu \mathrm{m}$ exposed oysters.

\section{DISCUSSION}

In these studies, PS particle toxicity and uptake at the cellular level were investigated in adult oysters (in vivo) and in isolated HP cells (in vitro). Using deconvolution fluorescent microscopy as well as epifluorescent microscopy, the results of these studies confirm that $50 \mathrm{~nm}$ particles are internalized by oyster cells following both in vitro and in vivo exposures. However, for the $3 \mu \mathrm{m}$ particles, epifluorescent studies indicated association of the particles with oyster cells but deconvolution microscopy indicated no intracellular accumulation of the particles, so the epifluorescence observed was due to extracellular attachment. Studies with epifluorescent techniques can only confirm association, but closer inspection of the HP cells using deconvolution microscopy indicated that only the $50 \mathrm{~nm}$ particles were internalized and were clustered in lysosomes and endosomes. This finding is consistent with other types of nanoparticles that have also been observed in the lysosomes of cells after exposure (Ringwood et al., 2009; Ma et al., 2011; Seydoux et al., 2014; Rocha et al., 2016). Due to the hydrophobic nature of PS particles, it is likely that the PS

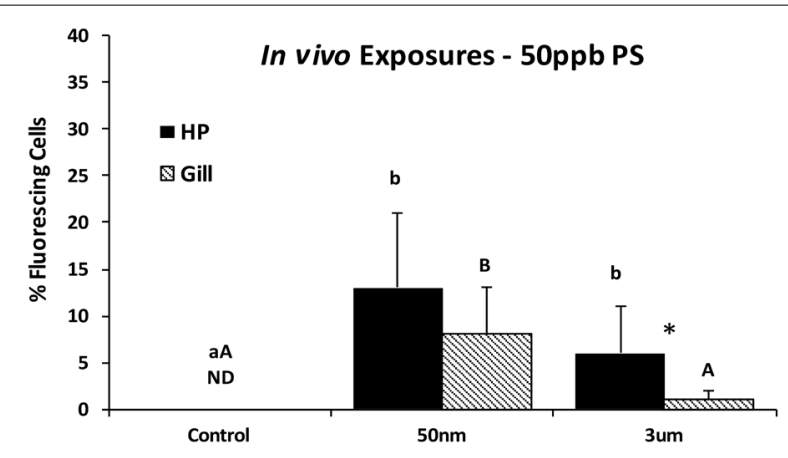

FIGURE 7 | Percent fluorescing cells as determined by epifluorescence analyses (Zeiss Axio Observer, 400x magnification) after exposure to PS particles for $48 \mathrm{~h}$ in vivo. Different letters indicate a significant difference within a tissue type $(p<0.05)$. Asterisks indicate a significant difference between tissue types (gill vs. HP; $p<0.05$ ). Values are means + standard deviations (HP tissues, $n=13-18$ oysters; gill $n=15-18$ oysters). ND, not detected. 
particles adhered to the outside of HP cells by Van der Wahl's forces where the $50 \mathrm{~nm}$ PS particles were subsequently taken up through pinocytosis and endocytosis pathways used by cells to take up small particles $(<150 \mathrm{~nm})$, where they would then be shuttled to the lysosomes (Alberts, 2004; Moore, 2006; Moore et al., 2014).

The percent accumulation for $50 \mathrm{~nm}$ PS particles determined using the epifluorescent microscope was comparable to the percent uptake calculated from the deconvolution microscope. This important finding indicates that epifluorescent microscopy which is more readily available in teaching and research laboratories can be used to study intracellular nanoparticle accumulation. Even in the epifluorescent images in these studies, the nanoparticles appeared more organized and consistent with lysosomal content, whereas the micron-sized particles had a more disorganized arrangement and looked more external.

Oysters are sessile filter feeders common in estuaries and they are known to remove particles in the $4-10 \mu \mathrm{m}$ size range with nearly 100\% efficiency (Haven and Morales-Alamo, 1970; Ward and Kach, 2009) making them an ideal model for particle uptake studies in the micron size range. While there is some debate about the filtration efficiency of bivalves below $1 \mu \mathrm{m}$, studies with oysters have shown that a reduction in waterborne bacteria occurs with oyster feeding, indicating that oysters are capable of capturing particles well below $1 \mu \mathrm{m}$ (Langdon and Newell, 1996; Jones et al., 2002). Filter feeding in oysters and other bivalves is accomplished by the highly ciliated gills. As the inhalant currents move water through the gills food particles are sorted and captured by the cilia and incorporated into mucous strings that are then moved toward the labial palps and mouth. Rejected particles are moved away from the labial palps through radial ridges on the mantle and expelled with the exhalent current as pseudofeces. Accepted particles are moved through the labial palps to an oral groove and finally into the mouth and digestive tract. Preliminary abrasion and breakdown of phytoplankton is facilitated by the crystalline style in the stomach, and small nutrient particles are moved into the digestive gland where they are taken up by endocytic pathways, and shuttled to lysosomes where the food particles are digested (Langdon and Newell, 1996; Gosling, 2015). While nano-sized particles may be too small for selective sorting by the gills, we believe that nanoparticles may be trapped in the mucous and moved incidentally into the digestive tract and HP tissues where they are then internalized. Studies with metal nanoparticles in a variety of bivalve species (oysters, mussels, and clams) have also indicated lower tissue concentrations of the base metal in gills compared to HP tissues (Tedesco et al., 2010; Garcia-Negrete et al., 2013), and greater toxicity in HP cells (McCarthy et al., 2013). Therefore, these studies with plastic particles indicate that while micron as well as nano-sized particles can be moved through the gills and digestive tract, the nano-sized particles are more readily accumulated in $\mathrm{HP}$ and digestive tissues, and are more readily accumulated inside cells.

For these studies, the exposure concentrations were based on mass, but it is recognized that the number of particles in the suspensions were much different. Based on the manufacturer's information, the total number of particles for the $100 \mathrm{ppb} 50 \mathrm{~nm}$ treatment would be $1.4 \times 10^{9}$, compared to $6.7 \times 10^{3}$ for the $3 \mu \mathrm{m}$ particles. Regardless of these differences, micron as well as nano particles that did interact with cells showed very different tendencies for cellular accumulation. We cannot eliminate the possibility that higher concentrations of the $3 \mu \mathrm{m}$ particles could result in some intracellular accumulation by phagocytosis. However, we actually observed higher cellular associations with the lower concentration (10 ppb) of the $3 \mu \mathrm{m}$ particles compared to the $100 \mathrm{ppb}$ treatment. Furthermore, phagocytosis of even one micron-sized particle would be readily detected by deconvolution microscopy, but no $3 \mu \mathrm{m}$ particles were observed intracellularly. In contrast, it is recognized that intracellular detection of the $50 \mathrm{~nm}$ particles would require the internalization of many particles to be detected by fluorescent microscopy, so it is possible that our studies could underestimate cellular accumulation of nano-sized particles.

Using a sensitive cellular toxicity assay, lysosomal destabilization, there was no evidence of toxicity for either the $3 \mu \mathrm{m}$ or $50 \mathrm{~nm}$ PS particles over the short-term duration of these exposures. Lipid peroxidation analyses were also conducted to evaluate oxidative damage for the in vitro exposures, but there was also no toxicity related to PS exposures (Gaspar, 2017). Therefore, even though particle accumulation (intracellular and extracellular) was observed, especially for $50 \mathrm{~nm}$ particles in HP cells, the bare PS particles were not overtly toxic for in vitro or in vivo exposures. Longer term exposures or chronic accumulation could contribute to cellular stress or lysosomal destabilization, especially if cells are unable to eliminate PS particles. When Browne et al. (2008) exposed mussels to 3 or $9.6 \mu \mathrm{m}$ PS particles for $3 \mathrm{~h}$ and then transferred them to clean SW, significant accumulation in the digestive tract was observed as well as transfer to the circulatory system that occurred within 3 days and persisted for over 48 days; these pulsed exposure studies also found no adverse effects on cell viability or phagocytic responses. Wegner et al. (2012) reported that the filtration rates (based on valve opening behavior) of mussels exposed to $50 \mathrm{~nm}$ PS particles over an 8-h period were significantly lower than control animals, suggesting the potential for long-term effects due to reduced feeding. In studies with HDPE (high density polyethylene)-fluff for 96 days at high concentrations, plastic particles were observed in lysosomes, and mussels developed granulocytomas associated with the fusion of phagosomes to the endolysosomal system, as well as a variety of other adverse effects on cellular functions (von Moos et al., 2012). Given that these were very heterogenous particle preparations (with a broad range of particle sizes, from $0-80 \mu \mathrm{m}$ ) with approximately $35-45 \%<50 \mu \mathrm{m}$, there could have been nano as well as small microplastics. A very extensive suite of cellular biomarkers was evaluated in mussels exposed to PE and PS (and in combination with pyrene) for 7 days and used in combination with bioaccumulation to develop a "weight of evidence (WOE)" risk table. PE was classified as having a "slight" risk, and PS was classified as having a moderate risk (Avio et al., 2015).

Recent longer term studies with oysters exposed to microplastics $(2$ and $6 \mu \mathrm{m}$ ) for 2-8 weeks indicated reduced gamete number and viability, and delayed settlement and 
metamorphosis of larvae from exposed parents (Sussarellu et al., 2016). Exposure studies conducted with oyster larvae indicated that larvae accumulated micro- and nano-PS, with greater accumulation of the nanoparticles, but no effects on larval growth were observed (Cole and Galloway, 2015). Overall these studies suggest that short term exposures to PS particles may not be too problematic, but chronic exposures or larger particles that clog respiratory and digestive systems may contribute to significant adverse effects.

Even if "clean" plastic particles are only moderately toxic, many plastics are also known to readily bind organic and metal pollutants. Even though our studies and others have not always observed toxicity, this "Trojan Horse" effect may be very problematic - especially with nanoplastics. Significant increases in toxicity and transfer of the pollutants from microplastics as they are processed through the digestive system of invertebrates have been documented (Mato and Isobe, 2001; Teuten et al., 2007; Teuten et al., 2009; Browne et al., 2013). In the Avio et al. (2015) risk classification described above, the combination of $\mathrm{PE}+$ pyrene or PS + pyrene resulted in a WOE risk of "major" or "severe," respectively.

Recent studies have also shown the presence of microplastics in mussels and oysters, farmed on the North Sea (Germany) and the eastern Atlantic Ocean (France; Van Cauwenberghe and Janssen, 2014), and also from natural populations of mussels and worms (Van Cauwenberghe et al., 2015), highlighting real concerns about potential impacts on consumers (including humans). Our studies indicate that plastic nanoparticles can be even more bioreactive than microplastics as they have a higher potential for intracellular accumulation, and could deliver toxins that readily affect cellular organelles and processes. In marine environments, the breakdown of an equivalent mass of plastic from microparticles to nanoparticles would produce more biologically available particles, as well as yield a net increase in surface area for the binding of pollutants. Environmental data

\section{REFERENCES}

Alberts, B. (2004). Essential Cell Biology. New York, NY: Garland Science Publications.

Andrady, A. L. (2011). Microplastics in the marine environment. Mar. Poll. Bull. 62, 1596-1605. doi: 10.1016/j.marpolbul.2011.05.030

Avio, C. G., Gorbi, S., Milan, M., Benedetti, M., Fattorini, D., d’Errico, G., et al. (2015). Pollutants bioavailability and toxicological risk from microplastics to marine mussels. Environ. Pollut. 198, 211-222. doi: 10.1016/j.envpol.2014. 12.021

Avio, C. G., Gorbi, S., and Regoli, F. (2017). Plastics and microplastics in the oceans: from emerging pollutants to emerged threat. Mar. Environ. Res. 128, 2-11. doi: 10.1016/j.marenvres.2016.05.012

Barnes, D. K. A., Galgani, F., Thompson, R. C., and Barlaz, M. (2009). Accumulation and fragmentation of plastic debris in global environments. Philos. Trans. R. Soc. B 364, 1985-1998. doi: 10.1098/rstb.2008.0205

Bocchetti, R., Fattorini, D., Pisanelli, B., Macchia, S., Oliviero, L., Pilato, F., et al. (2008). Contaminant accumulation and biomarker responses in caged mussels, Mytilus galloprovincialis, to evaluate bioavailability and toxicological effects of remobilized chemicals during dredging and disposal operations in harbour areas. Aquat. Toxicol. 89, 257-266. doi: 10.1016/j.aquatox.2008. 07.011

Browne, M. A., Dissanayake, A., Galloway, T. S., Lowe, D. M., and Thompson, R. C. (2008). Ingested microscopic plastic translocates to the circulatory continue to show increases in the amount of plastic wastes in marine environments, accumulating significantly in coastline as well as open ocean habitats, and marine organisms, raising alarms about this increasing threat (Derraik, 2002; Claessens et al., 2013; Reisser et al., 2013; Galloway and Lewis, 2016; Avio et al., 2017). Good advances have recently been made in developing protocols for extracting and quantifying microplastics, but no routine methodologies for nanoplastics are availabile. It is important to consider and characterize the potential impacts of the less visible nanoplastics as an emerging threat to sustainable marine ecosystems.

\section{AUTHOR CONTRIBUTIONS}

This work constituted part of the MS Thesis of TG, who with AR was responsible for conducting the exposures and the microscopic analyses, data analyses, and preparation of the manuscript. MP provided training and assistance with the epiflorescence analyses, and RC provided training and assistance with the fluorescent deconvolution analyses.

\section{FUNDING}

We gratefully acknowledge support for this work from Sigma Xi Student Grants-In-Aid, and UNCC Graduate School and Department of Biological Sciences.

\section{SUPPLEMENTARY MATERIAL}

The Supplementary Material for this article can be found online at: https://www.frontiersin.org/articles/10.3389/fmars. 2018.00345/full\#supplementary-material

system of the mussel, Mytilus edulis (L.). Environ. Sci. Technol. 42, 5026-5031. doi: $10.1021 /$ es800249a

Browne, M. A., Niven, S. J., Galloway, T. S., Rowland, S. J., and Thompson, R. C. (2013). Microplastic moves pollutants and additives to worms, reducing functions linked to health and biodiversity. Curr. Biol. 3, 2388-2392. doi: 10. 1016/j.cub.2013.10.012

Cadée, G. C. (2002). Seabirds and floating plastic debris. Mar. Poll. Bull. 44, 1294-1295. doi: 10.1016/S0025-326X(02)00264-3

Canesi, L., Ciacci, C., Fabbri, R., Marcomini, A., Pojana, G., and Gallo, G. (2012). Bivalve molluscs as a unique target group for nanoparticle toxicity. Mar. Environ. Res. 76, 16-21. doi: 10.1016/j.marenvres.2011.06.005

Claessens, M., Van Cauwenberghe, L., Vandegehuchte, M. B., and Janssen, C. R. (2013). New techniques for the detection of microplastics in sediments and field collected organisms. Mar. Poll. Bull. 70, 227-233. doi: 10.1016/j.marpolbul. 2013.03.009

Coen, L. D., Brumbaugh, R. D., Bushek, D., Grizzle, R., Luckenbach, M. W., Posey, M. H., et al. (2007). Ecosystem services related to oyster restoration. Mar. Ecol. Prog. Ser. 341, 303-307. doi: 10.3354/meps341303

Cole, M., Lindeque, P., Fileman, E., Halsband, C., Goodhead, R., Moger, J., et al. (2013). Microplastic ingestion by zooplankton. Environ. Sci. Technol. 47, 6646-6655. doi: 10.1021/es400663f

Cole, M., and Galloway, T. S. (2015). Ingestion of nanoplastics and microplastics by pacific oyster larvae. Environ. Sci. Technol. 49, 14625-14632. doi: 10.1021/acs.est.5b04099 
Denuncio, P., Bastida, R., Dassis, M., Giardino, G., Gerpe, M., and Rodríguez, D. (2011). Plastic ingestion in franciscana dolphins, Pontoporia blainvillei (Gervais and d'Orbigny, 1844), from Argentina. Mar. Poll. Bull. 62, 1836-1841. doi: 10.1016/j.marpolbul.2011.05.003

Derraik, J. G. B. (2002). The pollution of the marine environment by plastic debris: a review. Mar. Poll. Bull. 44, 842-852. doi: 10.1016/S0025-326X(02)00220-5

Faggio, C., Tsarpali, V., and Dailianis, S. (2018). Mussel digestive gland as a model tissue for assessing xenobiotics: an overview. Sci. Total Environ. 636, 220-229. doi: 10.1016/j.scitotenv.2018.04.264

Farrington, J. W., Tripp, B. W., Tanabe, S., Subramanian, A., Sericano, J. L., Wade, T. L., et al. (2016). Edward D. Goldberg's proposal of "the Mussel Watch": reflections after 40 years. Mar. Poll. Bull. 110, 501-510. doi: 10.1016/ j.marpolbul.2016.05.074

Galloway, T. S., Lewis, C. N. (2016). Marine microplastics spell big problems for future generations. Proc. Natl. Acad. Sci. U.S.A. 9, 2331-2333. doi: 10.1073/pnas. 1600715113

Garcia-Negrete, C. A., Blasco, J., Volland, M., Rojas, T. C., and Hampel, M. (2013). Behaviour of Au-citrate nanoparticles in seawater and accumulation in bivalves at environmentally relevant concentrations. Environ. Pollut. 174, 134-141. doi: 10.1016/j.envpol.2012.11.014

Gaspar, T. R. (2017). Polystyrene Particle Uptake and Their Potential to Act as a Trojan Horse for Pyrene to Oysters (Crassotrea virginica). Masters thesis, Charlotte, NC: University of North Carolina.

Gosling, E. (2015). "How bivalves feed", in Marine Bivalve Molluscs, ed. E. M. Gosling (Hoboken, NJ: John Wiley and Sons, Ltd.), 99-156.

Gray, A. D., and Weinstein, J. E. (2017). Size- and shape-dependent effects of microplastic particles on adult daggerblade grass shrimp (Palaemonetes pugio). Environ. Toxicol. Chem. 36, 3074-3080. doi: 10.1002/etc.3881

Haven, D. S., and Morales-Alamo, R. (1970). Filtration of particles from suspension by the American oyster Crassostrea virginica. Biol. Bull. 139, 248-264. doi: $10.2307 / 1540081$

Jambeck, J. R., Roland, G., Wilcox, C., Siegler, T. R., Perryman, M., Andrady, A., et al. (2015). Plastic waste inputs from land into the ocean. Science 347, 768-771. doi: 10.1126/science. 1260352

Jones, A. B., Preston, N. P., and Dennison, W. C. (2002). The efficiency and condition of oysters and macroalgae used as biological filters of shrimp pond effluent. Aquacult. Res. 33, 1-19. doi: 10.1046/j.1355-557X.2001.00637.x

Kennedy, V. S., Newell, R. I. E., and Eble, A. F. (1996). The Eastern Oyster: Crassostrea virginica. College Park, MD: Maryland Sea Grant College, 772.

Langdon, C. J., and Newell, R. I. E. (1996). "Digestion and nutrition in larvae and adults," The Eastern Oyster Crassostrea virginica, eds V. S. Kennedy, R. E. Newell, and A. F Eble (College Park, MD: Maryland Sea Grant), 231-269.

Ma, X., Wu, Y., Jin, S., Tian, Y., Zhang, X., Zhao, Y., et al. (2011). Gold nanoparticles induce autophagosome accumulation through size-dependent nanoparticle uptake and lysosome impairment. ACS Nano 5, 8629-8639. doi: $10.1021 / \mathrm{nn} 202155 \mathrm{y}$

Martins, J., and Sobral, P. (2011). Plastic marine debris on the portuguese coastline: a matter of size? Mar. Pollut. Bull. 62, 2649-2653. doi: 10.1016/j.marpolbul. 2011.09.028

Mato, Y., and Isobe, T. (2001). Plastic resin pellets as a transport medium for toxic chemicals in the marine environment. Environ. Sci. Technol. 35, 318-324. doi: 10.1021/es0010498

McCarthy, M. P., Carroll, D. L., and Ringwood, A. H. (2013). Tissue specific responses of oysters, Crassostrea virginica, to silver nanoparticles. Aquat. Toxicol. 138-139, 123-128. doi: 10.1016/j.aquatox.2013.04.015

Mattsson, K., Hansson, L. A., and Cedervall, T. (2015). Nano-plastics in the aquatic environment. Environ. Sci. Process. Impacts 17, 1712-1721. doi: 10. 1039/C5EM00227C

Moore, M. N. (2006). Do nanoparticles present ecotoxicological risks for the health of the aquatic environment? Environ. Int. 32, 967-976. doi: 10.1016/j.envint. 2006.06.014

Moore, M. N., Allen, J. I., McVeigh, A., and Shaw, J. (2014). Lysosomal and autophagic reactions as predictive indicators of environmental impact in aquatic animals. Autophagy 2, 217-220. doi: 10.4161/auto.2663

PlasticsEurope (2018). Plastics the Facts-2017. Wemmel: PlasticsEurope.

Regoli, F. (1992). Lysosomal responses as a sensitive stress index in biomonitoring heavy metal pollution. Mar. Ecol. Prog. Ser. 84, 63-69. doi: 10.3354/meps084063

Reisser, J., Shaw, J., Wilcox, C., Hardesty, B. D., Proietti, M., Thums, M., et al. (2013). Marine plastic pollution in waters around Australia. PLoS One 8:e80466. doi: 10.1371/journal.pone.0080466
Ringwood, A. H., Conners, D. E., and Hoguet, J. (1998). The effects of natural and anthropogenic stressors on lysosomal destabilization in oysters, Crassostrea virginica. Mar. Ecol. Prog. Ser. 166, 163-171. doi: 10.3354/meps166163

Ringwood, A. H., Hoguet, J., Keppler, C., and Gielazyn, M. (2004). Linkages between cellular biomarker responses and reproductive success in oysters. Mar. Environ. Res. 58, 151-155. doi: 10.1016/j.marenvres.2004.03.010

Ringwood, A. H., Conners, D. E., Hoguet, J., Ringwood, L. A. (2005). "Lysosomal destabilization assays in estuarine organisms," in Techniques in Aquatic Toxicology, Vol. 2, ed. G. K. Ostrander (Boca Raton, FL: CRC Press, Taylor and Francis), 287-300.

Ringwood, A. H., Levi-Polyachenko, N., and Carroll, D. L. (2009). Fullerene exposures with oysters: embryonic, adult, and cellular responses. Environ. Sci. Technol. 43, 7136-7141. doi: 10.1021/es900621j

Rocha, T. L., Gomes, T., Durigon, E. G., and Bebianno, M. J. (2016). Subcellular partitioning kinetics, metallothionein response and oxidative damage in the marine mussel Mytilus galloprovincialis exposed to cadmium-based quantum dots. Sci. Total Environ. 554-555; 130-141. doi: 10.1016/j.scitotenv.2016. 02.168

Seydoux, E., Rothen-Rutishauser, B., Nita, I. M., Balog, S., Gazdhar, A., Stumbles, P. A., et al. (2014). Size-dependent accumulation of particles in lysosomes modulates dendritic cell function through impaired antigen degradation. Int. J. Nanomedicine 9, 3885-3902. doi: 10.2147/IJN.S64353

Sussarellu, R., Suquet, M., Thomas, Y. Lambert, C., Fabioux, C., Pernet, M. E. J., Le Goïc, N., Quillien, V., et al. (2016). Oyster reproduction is affected by exposure to polystyrene microplastics. Proc. Natl. Acad. Sci. U.S.A. 113, 2430-2435. doi: 10.1073/pnas.1519019113

Tedesco, S., Doyle, H., Blasco, J., Redmond, G., and Sheehan, D. (2010). Exposure of the blue mussel, Mytilus edulis, to gold nanoparticles and the pro-oxidant menadione. Comp. Biochem. Physiol. Part C 151, 167-174.

Teuten, E. L., Rowland, S. J., Galloway, T. S., and Thompson, R. C. (2007). Potential for plastics to transport hydrophobicm contaminants. Environ. Sci. Technol. 41, 7759-7764. doi: 10.1021/es071737s

Teuten, E. L., Saquing, J. M., Knappe, D. R. U., Barlaz, M. A., Jonsson, S., Björn, A., et al. (2009). Transport and release of chemicals from plastics to the environment and to wildlife. Philos. Trans. R. Soc. B 364, 2027-2045. doi: $10.1098 /$ rstb.2008.0284

Van Cauwenberghe, L., and Janssen, C. R. (2014). Microplastics in bivalves cultured for human consumption. Environ. Pollut. 193, 65-70. doi: 10.1016/j.envpol. 2014.06.010

Van Cauwenberghe, L., Claessens, M., Vandegehuchte, M. B., and Janssen, C. R. (2015). Microplastics are taken up by mussels (Mytilus edulis) and lugworms (Arenicola marina) living in natural habitats. Environ. Pollut. 199, 10-17. doi: 10.1016/j.envpol.2015.01.008

von Moos, N., Burkhardt-Holm, P., and Köhler, A. (2012). Uptake and effects of microplastics on cells and tissue of the blue mussel Mytilus edulis L. After an experimental exposure. Environ. Sci. Technol. 46, 11327-11335. doi: 10.1021/ es302332w

Ward, J. E., and Kach, D. J. (2009). Marine aggregates facilitate ingestion of nanoparticles by suspension-feeding bivalves. Mar. Environ. Res. 68, 137-142. doi: 10.1016/j.marenvres.2009.05.002

Wegner, A., Besseling, E., Foekema, E. M., Kamermans, P., and Koelmans, A. A. (2012). Effects of nanopolystyrene on the feeding behavior of the blue mussel (Mytilus edulis L.). Environ. Toxicol. Chem. 31, 2490-2497. doi: 10.1002/etc. 1984

Weinstein, J. E., Crocker,B. K,., and Gray, A. D. (2016). From macroplastic to microplastic: degradation of high density polyethylene, polypropylene, and polystyrene in a salt marsh habitat. Environ. Toxicol. Chem. 35, 1632-1640. doi: 10.1002/etc.3432

Conflict of Interest Statement: The authors declare that the research was conducted in the absence of any commercial or financial relationships that could be construed as a potential conflict of interest.

Copyright (C) 2018 Gaspar, Chi, Parrow and Ringwood. This is an open-access article distributed under the terms of the Creative Commons Attribution License (CC BY). The use, distribution or reproduction in other forums is permitted, provided the original author(s) and the copyright owner(s) are credited and that the original publication in this journal is cited, in accordance with accepted academic practice. No use, distribution or reproduction is permitted which does not comply with these terms. 